\title{
Assessment of Ecotourism Challenges in Okwangwo Division of Cross River National Park, Nigeria
}

\author{
Chris Diminy $\mathrm{i}^{*} \quad$ Gregory Atemgweye $^{1} \quad$ Doris Agaku $^{1} \quad$ Chris Odey $^{2}$ Dominic Anyanwu ${ }^{3}$ \\ 1.Department of Tourism Studies, University of Calabar, Calabar, Nigeria \\ 2.Department of Hospitality and Tourism Management, Cross River University of Technology, Calabar, Nigeria \\ 3.Department of Hospitality Management, Federal Polytechnic, Auchi, Nigeria
}

\begin{abstract}
Nigeria is endowed with rich cultural and natural resources which are potentials for ecotourism development. Unfortunately, despite all the resources, ecotourism in Nigeria has not been effectively developed to achieve its objectives. The study was undertaken to evaluate the challenges of ecotourism development in Okwangwo Division of Cross River National Park through field observation and oral interview of community members, park staff and government officials, who were purposively selected. The study shows that the major problems hindering the development of ecotourism in the area include poor funding, inadequate infrastructural facilities, increased population of park inhabitants and the inability of government to relocate enclave communities out of the park. Indiscriminate bush burning, logging, poaching and confrontation between park staff and local residents were also identified among the principal factors hampering ecotourism development in Okwangwo Division. It is therefore imperative for government to be more committed by allocating adequate funding for the project, provide the local communities with social amenities, intensify environmental education and also relocate enclave communities out of the park for effective protection of resources by park staff.
\end{abstract}

Keywords: Ecotourism, challenges, assessment, national park, Okwangwo Division

DOI: $10.7176 / \mathrm{JTHS} / 49-03$

Publication date:May $31^{\text {st }} 2020$

\section{Introduction}

Tourism has been technically defined as the activities of persons travelling outside their usual environment for less than twelve months, and whose main purpose of travel is not connected with an activity remunerated from the place visited (UNWTO, 2012). It is one of the leading and fastest growing industries in the world that is counted among the major economic sectors that promote community development through job creation and income generation (Menbere and Menbere, 2017; Ketema, 2015). With the advent of technology and globalization, tourism has recorded a tremendous growth all over the world. For instance, in 2018, tourism grew at $3.9 \%$, contributing 8.8 trillion dollars and 319 million jobs to the world economy (WTTC, 2019). In most developing countries, tourism contributes about $80 \%$ of their total foreign exchange earnings (Mequanint \& Gebremedhin, 2015).

During the peak of insurgency that engulfed most parts of Nigeria especially, the North Central and Eastern regions (parts of Borno, Adamawa and Taraba State in the North-east and Plateau, Nasarawa and Benue States in North-central), the tourism industry suffered great setbacks in international receipts. However, in the last few years, the Nigerian tourism industry has regain strength in the international market following the bilateral agreement with most generating countries and the current peace, stability and government attention to revive the nation's tourism sector. In 2013, travel and tourism investment in Nigeria was NGN264.2bn or $4.8 \%$ of total investment. This figure was forecasted to rise by $5.1 \%$ per annum over the next ten years to NGN438.9bn ( $4.4 \%$ of total) in the year 2024 (WTTC, 2014). This trend revealed a continuous growth in international arrivals and spending, therefore making tourism one of the major economic sectors in Nigeria.

The tourism sector is made up of many categories and ecotourism is one of its factions that is currently gaining support in development approach because of its ability to influence community empowerment and enhance cultural and environmental conservation (World Bank 2013). The term ecotourism was first defined in the early 1980s by Ceballos-Lascurain as "tourism that involves travelling to relatively undisturbed natural areas for the purpose of learning, admiring and enjoying the scenery and its wild plants and animals, as well as any existing cultural aspects of both past and present found in these areas" (Ceballos-Lascurain, 2006). Ecotourism advocates scientific and aesthetic approach. This however, does not imply that the ecotourist must be a professional scientist or artist. The main point is that people who practice ecotourism have the opportunity of immersing themselves in nature in such a way that most people cannot enjoy in their normal urban life. Ecotourism is a new form of tourism that is promoted for its ability to reduce the negative impact of mass tourism at destinations. It has received the attention of developing nations because of its conservation role and significance in economic development, which contribute to the welfare of local communities. With the introduction of environmental education as an integral part of ecotourism to enhance customer satisfaction, many developing regions had tapped from this single inherent element to effectively market their serene natural habitats as tourism products (Pookhao, 2014).

Osunsina, Ogunjinmi, Meduna and Oyeleke (2008) stated that the only way to maximize environmental, 
social and economic benefits of tourism is by adopting ecotourism option. Buller (2000) cited in Osunsina et. al (2008) holds the view that ecotourism promotes environmental ethics, supports preservation of cultural and natural heritage as well as the welfare of host communities. Okpoko, Okonkwo and Diminyi (2011) added that ecotourism has a multitude of impacts on people's lives and on the environment. Sebele (2010) conducted a study on the benefits and challenges of community based ecotourism venture in Botswana and found out that ecotourism can also provide resources for environmental conservation and management and an incentive for the conservation and sustainable use of public and private land. Tobias (2007) evaluated ecotourism in Laikipia and concluded that ecotourism has been promoted as a means to generate local employment and income in forest regions without the adverse effects attributed to timber and non-timber forest product extraction and agriculture. Ebin (2003) stated that the only benefiting opportunities for many remote communities in the past especially in developing countries were the extracting industries (logging, fishing, game poaching etc) which often leave an unacceptable long-term environmental damage with detrimental impacts on local communities. Today, ecotourism is fast engulfing these destructive activities with its significant contribution to deliver benefits that do not involve widespread sociocultural and environmental deterioration in remote communities (Bates 1991; Tobias 2007; Agbor 2014).

Undoubtedly, ecotourism has proven to be worthwhile development alternative in many developed and developing nations (Allock, Jones, Lane \& Grat 1994; Chambers 1995; Johnston 2000; Liu 2003; Buckley 2004; Osunsina et. al 2008; Sebele 2010) especially as it creates long-lasting and positive socio- economic, cultural and environmental changes in the host region, it is certainly not without deficiencies. As argued by Ceballos (2002) "because ecotourism largely stem from the creative ability of man, it is certainly imperfect...there is no pure form of ecotourism anywhere in the world." A wide margin exists in different dimensions between theoretical and practical application of ecotourism. These deficiencies are explained in tourism literatures by various scholars. For instance, Cater (2006) describes ecotourism as a western gimmick in order to expose the lack of logical thoughts in the relationship between developed and third world countries, thus strengthening their control over developing nations. Abdul (2009) in a study on the impacts of ecotourism in Socotra Island and discovered that ecotourism projects were not successful in the region because of its inability to provide alternative means of livelihood for the local people and also relocate them out of the park boundary. An assessment of the Pacific Island by Scheyvens (1999) reveals that ecotourism was rather used as a tool for market development and profit maximization than practical implementation of its purported principles. Eja, Otu, Agbor and Emri (2013) avers that despite the ecotourism potentials in Cross River National Park, ecotourism have not been properly developed to achieve the desired objectives. Government have failed to provide infrastructural development in the area such as electricity, communication network, portable water, health facilities, good schools and good road network thus; hindering the mobilization of resources that would have influenced the growth of ecotourism to bring the much needed socioeconomic benefits in the area.

Ecotourism is presented here to include appreciation and prudent management of local environment and cultures to generate socio-economic benefits and improve standard of living for host communities. It is proposed as a way for communities with otherwise marginal cultural or ecological resources to develop. Okwangwo Division of Cross River National Park with immense ecotourism potentials is characterized by underdevelopment. Anselem and Nzanosin (2016) reveals that ecotourism is not well developed in the area compared to the available resources, which has affected the number of visitors to the park. Figure 1 shows the sporadic nature of tourist flow to the park division between 2010 and 2018 . 


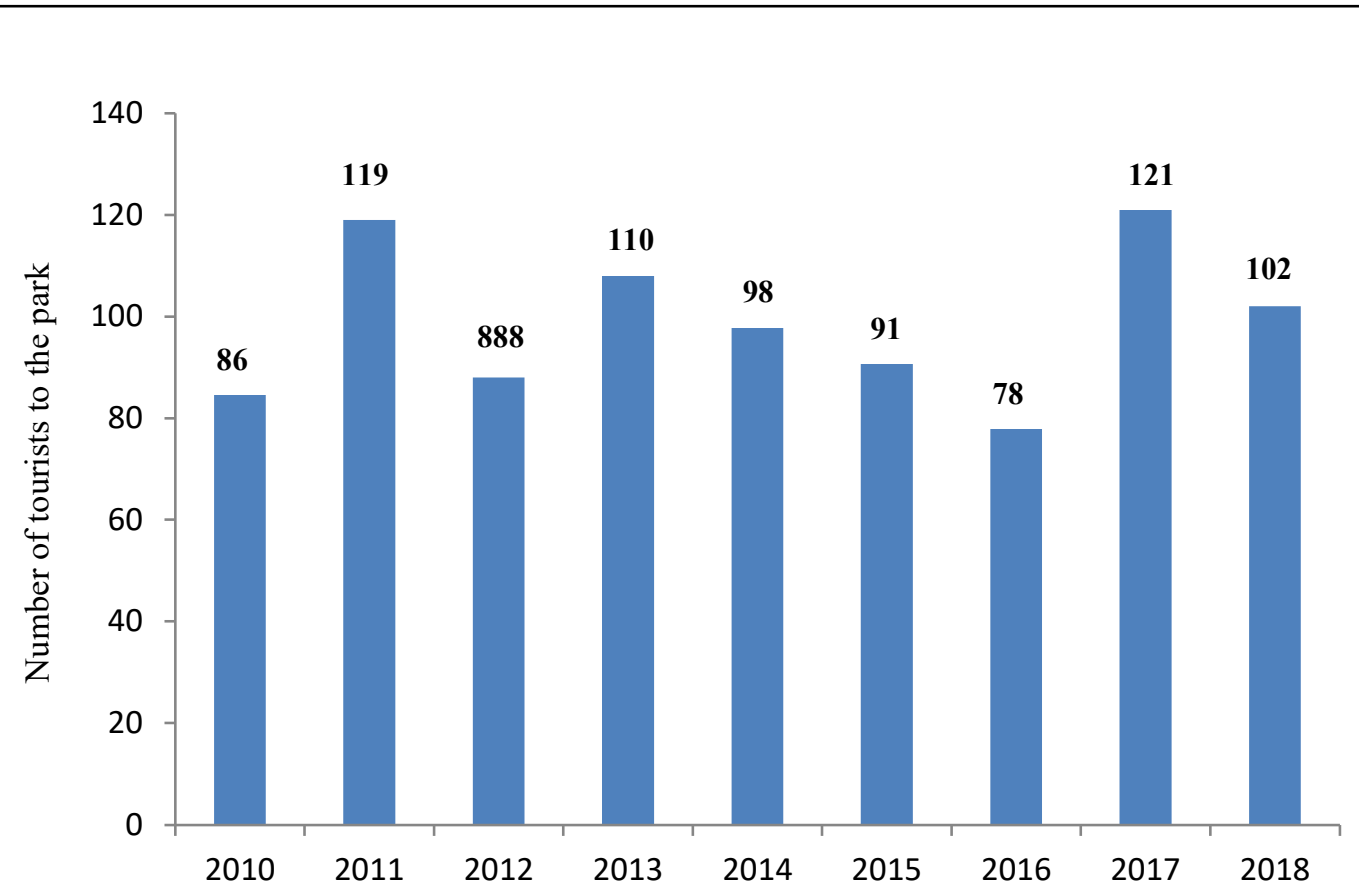

\section{Figure 1: The trend of tourist flow to Okwangwo Division of Cross River National Park}

Effective ways of improving local governance, promoting conservation and ensuring benefits for the local people have not been developed. However, to properly manage the environment sustainably and make the resources valuable to local people, ecotourism should be given priority to improve the livelihood of local people living within and around the park division. A number of studies revealed that detail study and inventory of potential attractions, adoption of effective ecotourism plans, implementation of strategies and general enhancement of stakeholders role are the gate ways to ecotourism development in any part of the world (Aynalem, 2016; Bale Mountain National Park, 2014; Nwahia, Omonona, Oyeabor \& Balogun, 2012; Ayele, 2011). Therefore, studying the major impediments to ecotourism development is imperative as it will help developers to proactively seek effective preventive and mitigation measures. This research paper tries to identify the challenges of ecotourism development in Okwangwo Division of Cross River National Park, South East Nigeria.

\section{Methodology}

\subsection{Study Area}

This research was conducted in Okwangwo Division of Cross River National Park. The park is one of the eight national parks in Nigeria, segmented into two non-contigious parts: Oban and Okwangwo. The Okwangwo Division is the smallest part of the park comprising serveral communities known as support zone communities, within and adjacent the park boundary. This division was selected because ecotourism is not well developed compared to Oban Division even when the programme was launched several years ago. The Division is located in the North eastern part of Cross River State, found in Boki Local Government Area (Figure 2). It extends along the Cameroon border between latitudes $6^{\circ} 17^{\prime \prime} \mathrm{N}$ and $6.28^{\circ} 33^{\prime \prime} \mathrm{N}$ of the Equator and longitudes $9^{\circ} 14^{\prime \prime} \mathrm{E}$ and $9.23^{\circ} 33^{\prime \prime} \mathrm{E}$ of the Greenwich Meridian, covering a total land area of 1000sq with an altitude of $1500 \mathrm{~m}-1700 \mathrm{~m}$ above sea level (Austine, Sijah, and Rebecca, 2014). 


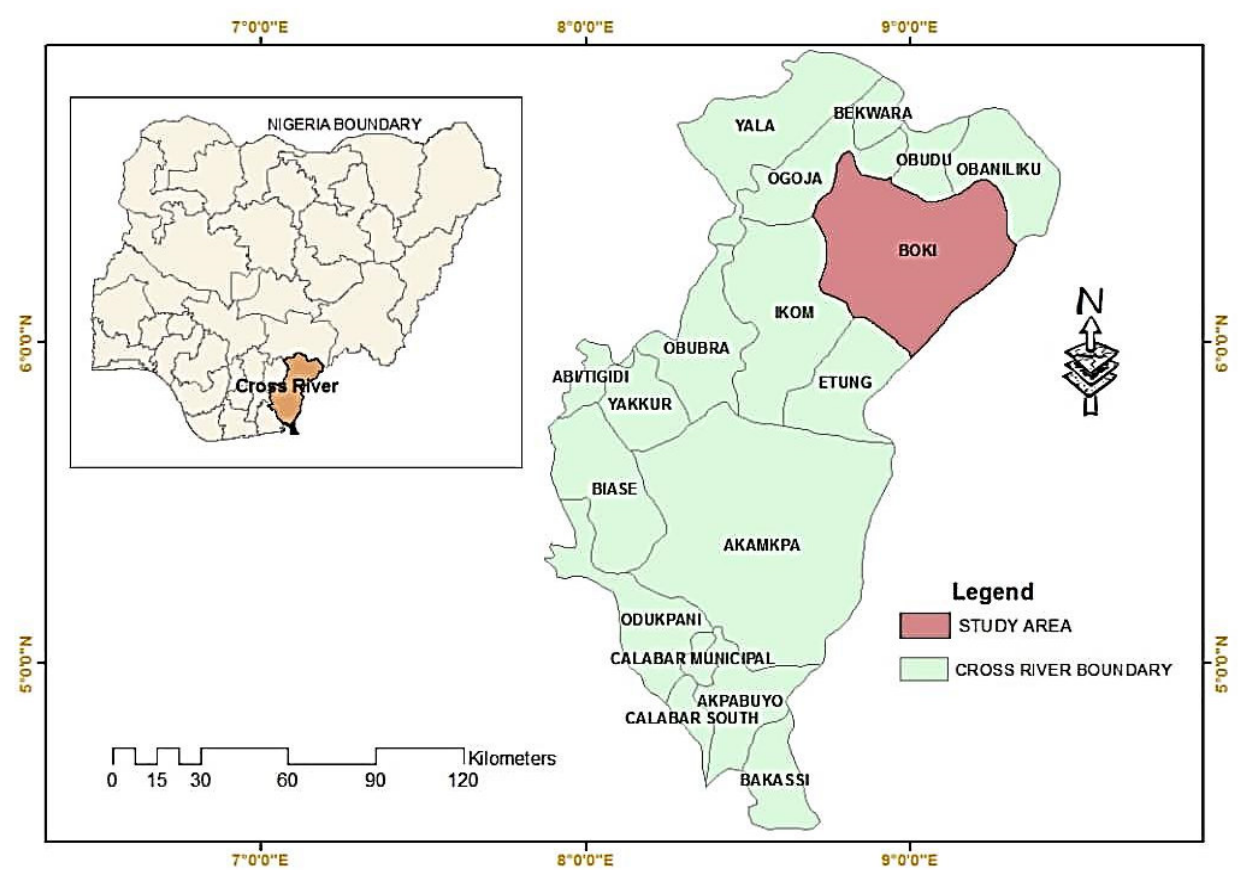

Figure 2: Location Map of Study Area; from top left: Map of Nigeria showing Cross River State

The divisional headquarter is in Butatong, $460 \mathrm{~km}$ from Calabar; the capital city of Cross River State. The total population inhabiting the division is about 4794. This figure was arrived at using 2006 population census figure (Ewah, 2013) and extrapolating it to 2018 using the estimated growth rate of 3\%. The park is characterized by cold climate with an ambient temperature of $14^{\circ}-16^{\circ} \mathrm{C}$ (Eneji, 2015). The local communities that were involved in the study were purposively selected because they were considered to be knowledgeable in their views of ecotourism challenges in the area. A total of 97 key informants from 10 communities, CRNP, University of Calabar, government offices and Non-Governmental Organizations (NGOs) were purposively selected for their familiarity with ecotourism development. That said, 85 community members, 5 park staff, 2 lecturers, 3 government officials and 2 NGO staff were involved in the study.

\subsection{Data Collection}

This research was carried out between November, 2018 and March, 2019. To assess the challenges of ecotourism in Okwangwo, different methods of data collection were adopted to maintain credibility. Field visit was accompanied by in-depth interviews and focus group discussions (FGDs) to identify the issues affecting ecotourism development in the area. Photographs were also taken to support the evidences of ecotourism challenges. However, in order to broaden the scope of the study, existing literature and relevant park records were also reviewed. In-depth interviews were conducted with 97 key informants purposively selected from the sample communities, CRNP, University of Calabar, government offices and NGOs. These informants were considered to have ecotourism experience. Field observation was used to gather information that was not easy to access through inter-personal communication and to cross-check the information obtained from interviews, group discussions and questionnaire. Observable facts were recorded with field notes while digital camera and Global Positioning System (GPS) were used for pictorial data and mapping of site respectively. In addition, publish and unpublished documents (park reports and bulletins, publications from government offices and case study materials) were also used to support the study.

\subsection{Data Analysis}

Data were analyzed in the form of narration. First the researchers categorized the information into major headings, producing a full transcript of each respondent's comments from where a summarized version was derived. Thereafter, the responses were analyzed and interpreted by synthesizing the views of the various interviewees in relation to the arguments presented in the literature review.

\section{Result/Findings}

The management of Okwangwo Division of Cross River National Park operates under five main departments. These are administrative and finance, participatory management, research and monitoring, park protection and trans-boundary conservation. Each department performs particular functions directed towards safeguarding the environment for the ultimate development of ecotourism. The study of the challenging factors for ecotourism 
development in the Division was approached in two ways, first from reports and views of the park authority, NGOs and Host communities and secondly from direct observation. According to the divisional head of the park and Wildlife Conservation Society (WCS) sectional leader, the major challenge of ecotourism development in the area is infrastructural development. According to them, the area lack infrastructure which require huge capital to put in place especially in the areas of transportation and communication, electricity and good water, health facilities and education. This development is predicated on poor funding of the ecotourism project by government. The development of tourism of any kind is capital intensive and requires huge amount of money. Park authorities expressed frustration about the inability of the government to provide adequate funding for the project. The divisional head remarks as follows:

The government has always found it difficult to release enough money to enable us execute projects in the area. Out of the total amount proposed for this project, we have not received up to $25 \%$ support. The local residents on the other hand are expecting to see rapid positive changes ... this is the reasons we are accused of not involving the landlords in the planning process (Karim, 2016, personal communication).

Direct observation supports the above claim as some projects that started two years ago by the government have not been completed (see plates a and b). Park authorities cannot even go round to inspect project due to poor funding. They however hope that government will soon release funds to execute the projects.

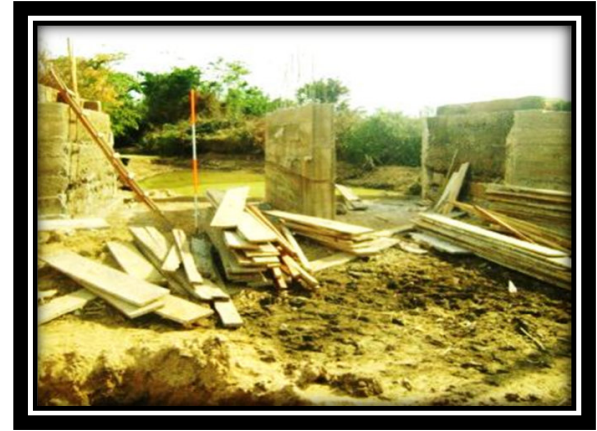

a) Abandon concrete bridge at Okon river

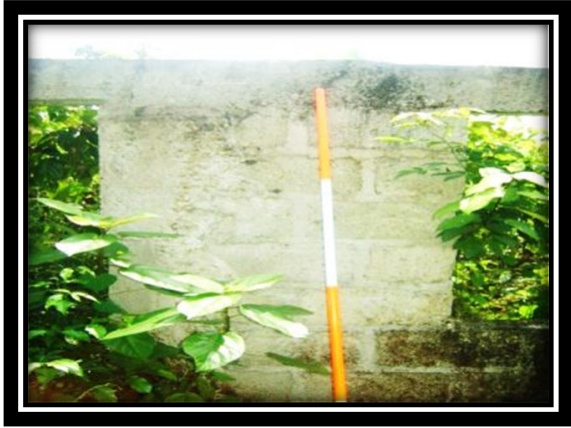

b) Abandon building of the proposed Tourists' village at Bamba

The $18 \mathrm{~km}$ path way from the park head office at Butatong to Okwangwo and $32 \mathrm{~km}$ from the head office to Okwa are bush tracks (see plate d) that are highly inundated by overflowing streams and rivers during rainy season. The Okwa-Ballegete road and Okwagwo-Okwa road are also bush tracks without bridges or concrete culverts across the fast flowing rivers, thus hindering accessibility particularly during rainy season. Direct observation shows that the park can only be accessed on foot and this is mostly done by rangers and eco-guides. Lack of motorized road network and the difficulty with which one can access the park even on foot particularly during rainy season is an important limiting factor to ecotourism development in the area.

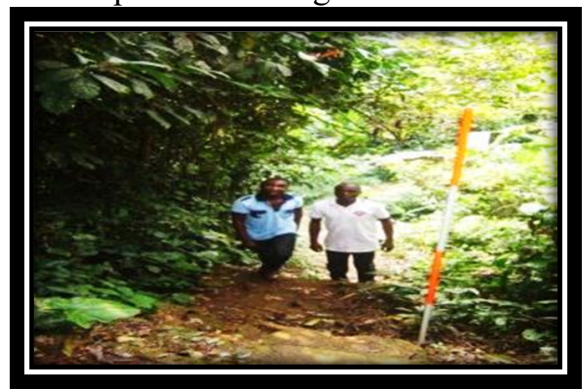

c) The researcher on a rough road to Ballegete 1

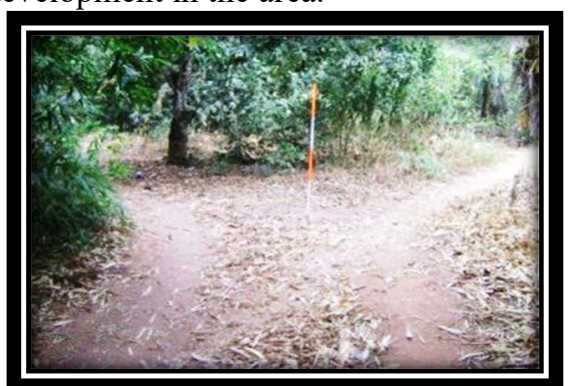

d) Road junction showing track roads leading to Okwangwo and Okwa from Butatong

In corroboration of the above claim, a participant at Okwa commented that, "Our crops get spoiled because we cannot take them to the market especially during the rainy season. We are always locked-up here." Enclave communities are disadvantaged by poor accessibility. Often time, the villagers trek for more than 6 hours to Butatung to market their farm produce. The only alternative means of transportation is commercial motorcycle which is not often available. The fare is also astronomically high. It costs about $\$ 4,500.00$ from Okwa and N2,000.00 from Okwangwo to Butatong respectively. This difficulty has greatly affected the local economy of the enclave communities. A local farmer at Okwangwo complains as follows:

We find it very difficult to market our farm produce as a result of this road problem; our harvests do not reach the market in good condition and this affect 
the price. A bunch of plantain that could have ordinarily been sold for $\$ 800$ will now be sold at $\$ 300.00$ or less in the market and if we manage to see any buyer here we sell just for a 100.00 or 150.00 at most. This accessibility constraint has affected our income level and local economy in general (Oyong, 2016, personal communication).

Communication facilities are also lacking in the area. The park is cut-off completely from telecommunication network and even radio and TV networks. At most, signals are received from the Cameroon local FM network, which broadcasts in French and presents Cameroon local news contents. This communication hindrance also affects the activities of ecotourism in the area. Apart from Butatong that has recently been provided with borehole at the park head office, no other community has portable water or electricity supply. However, few families have small generating plants that they occasionally make use of to light their houses and also give out for rent during funeral and festivals. Villagers depend solely on local streams for water supply which often expose them to cholera and other water-borne diseases. During Focus Group Discussion at Okwangwo, respondents remarked that they are suffering from many sicknesses as a result of bad water. The park authority has restricted the access of local residents to certain sources of water that they perceive as good for drinking for fear that they will engage in illegal fishing and collection of other aquatic resources. They however, call for government assistance to provide them with alternative sources of drinking water by sinking boreholes. Field observation revealed that the only source of good water is the borehole at the Divisional Headquarter in Butatong, while the other communities particularly enclave communities (Okwangwo and Okwa) have challenges in getting drinking water especially during dry the season.

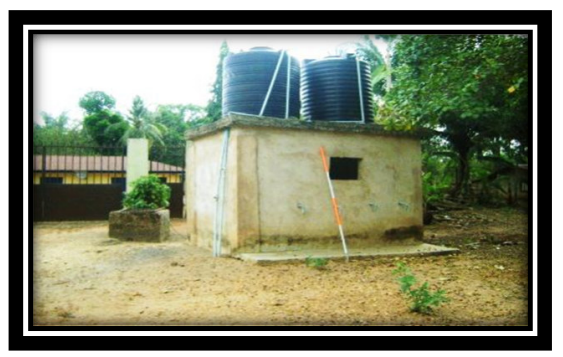

e) The overhead tanks that supply water from the Borehole at the divisional head office of the park.

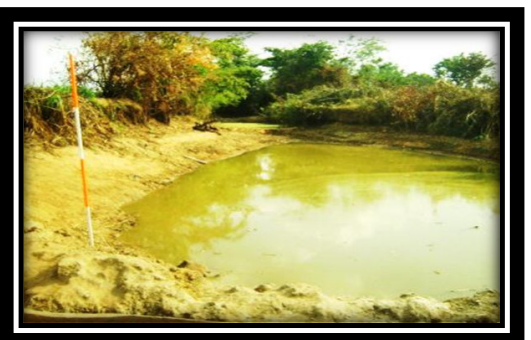

f) Source of drinking water at Okwa 1

During field work, the researchers had to travel with bags of sachet water to Okwa, Ballegete and Okwangwo villages. Park Rangers were also seen moving with their drinking water during patrol in most of these communities. This lack of portable water and absence of electricity supply are also challenges to effective ecotourism development in Okwangwo zone of Cross River National Park. .

Apart from Kayang 1 and 2 which are at the Obudu-Ikom highway and Butatong which is about two kilometers from the highway, no other community in the park has a functional dispensary or health centre. Interview result and direct observation revealed that there is neither a dispensary nor a functional healthcare facility in Bellegette 1 and 2, Okwa 1 and Okwa 2 and Okwangwo communities. Local residents of the enclave communities take their sick people to the primary health centre at Butatung, which is about $18 \mathrm{~km}$ from Okwangwo and $32 \mathrm{~km}$ from Okwa respectively. The villagers rely mainly on traditional herbs for treatment particularly during rainy season that they are often constrained by flooding and other accessibility problems to take their sick ones to the health centre at Butatong.

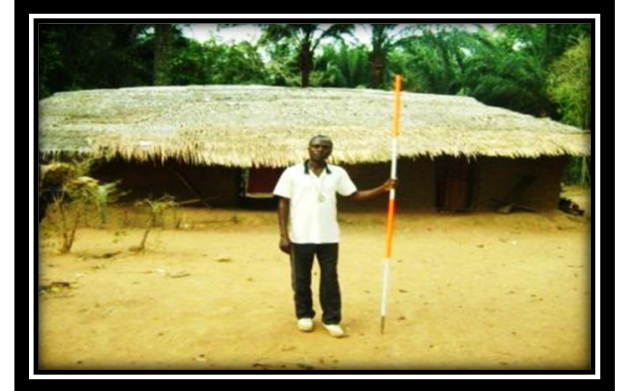

g) A non-functional health centre at Okwangwo

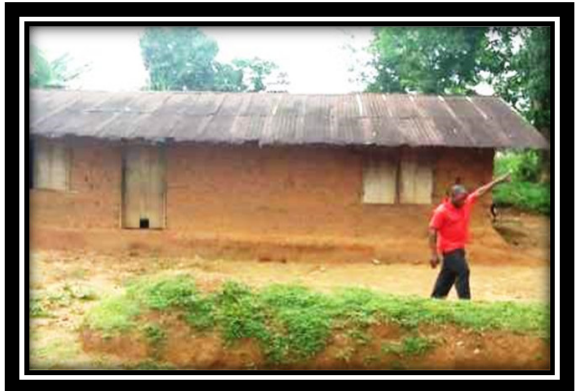

h) A traditional medicine house at Okwa

There is high level of illiteracy especially within enclave communities. Very few people in Okwa and Balegette understand and communicate in English. Findings show that there is only one primary school and a secondary school at Okwangwo that is recently built by the Cross River Border Commission under the supervision of the State Universal Basic Education Board (SUBEB). Okwa 1 and 2 and Ballegete 1 and 2 have no schools and are very far from Okwangwo. The long distance from Ballegete and Okwa to Okwangwo discourages most 
children from going to school who, instead, turn to farming and hunting in the park in order to earn a living. The high level of illiteracy hinders effective collaboration between the park authorities and the villagers, and this in turn, affects smooth planning and development of ecotourism within Okwangwo zone. It is pertinent to note that as there are variabilities in the park management programmes and team, which complement and contradict each other as far as park management is concerned; there is also variability of the constraints to successful ecotourism planning and development within the park. Apart from the major challenges highlighted above, which have direct influence on ecotourism development in the division, field observation especially during focus group discussion reveals a range of other factors that are indirectly affecting the planning and development of ecotourism in the area. These factors include: The local residents complain of being confused on who and what to believe. One resident commented:

Everybody and group is assuming the role of a boss, giving us instructions because we are villagers. Rangers are now carrying out the duties of Okwango Forest Conscience Organization (OFCO) chairman and Conservation Association of Mbe Mountain (CAMM) president. Today we are told to do this, tomorrow another group will come with their own instruction, we are tired, and we don't even know who to follow again (Agbor, 2016, personal communication).

No doubt, situations like this bring about miss-information and confusion in the programme of activities. The population of communities living in and around the park has increased with a corresponding high rate of livelihood needs. Direct observation shows that some communities were getting enlarged, while new villages are being established. Host communities especially enclave communities depend on agricultural products and harvesting of Non Timber Forest Products (NTFPs) and hunting to generate income for their sustenance. These are no longer available due to ecotourism project. One participant said:

It is very difficult to feed my family now unlike before when we were just two without any job. I have six children now; I did not attend any school, which would have given me the opportunity to look for government job in the city. The only way to survive is by getting forest resources. This situation is also experienced by all families because our population in this community has increased. We use to have just about eleven buildings with less than thirty people, but now we have very close to one hundred houses with more than one thousand people. How can we survive without the forest resources (Gbonshi, 2016, personal communication)?

Consequently, the host communities especially, those inside the park defy the park laws to exploit the forest resources (plates i-n) for survival. When participants were asked if they are aware of the park laws, they said, "we know that one of the major park laws is that we should not exploit the park resources. But in a situation where we have no employment, no education, no alternative means of survival, and we are very poor, then we have no option than to violate the park rules.' Result also revealed that only six persons from support zone communities have formal employment as eco-guides in the park. According to Kothari, Singh, and Suri (1996), restriction or ban on access to the utilization of the forest for livelihood needs, especially under the circumstances of illiteracy, unemployment and poverty, can result in frustration and subsequently provoke aggressive behaviour towards any protected area.

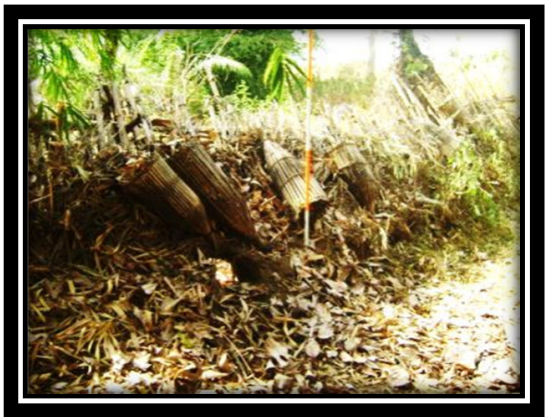

i) Fishing traps at Mache River

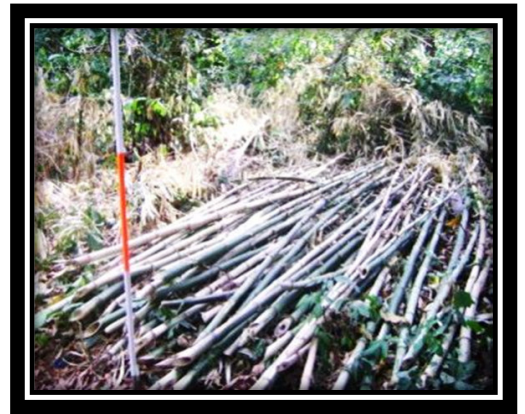

j) Roofing materials; Indian bamboo

Respondents further stated that "as oil is to the people of Niger Delta so is our forest to us, if the government does not take us serious and do something immediately we will be forced to invade the park and nobody can stop us." Direct observation revealed that a lot of physical damage is currently going on despite the people's knowledge of environmental conservation. However, the local people said they will observe conservation ethics and refrain from destructive activities in the park if the government recognizes them and assists them to develop like other communities. They are asking for infrastructural development, scholarships for their children, employment and 
general empowerment programmes.

\section{Discussion}

A range of factors including electricity, communication network, portable water, health facilities, good schools and good roads militate against effective ecotourism planning and development in Okwangwo zone. Social amenities play a vital role in the development of tourism. Apart from the benefits derived by host communities, amenities also constitute a major determinant factor for tourist's arrival. The absence of vehicular roads within the park does not only hinder the movement of enclave communities, eco-guides and tourists in and out of the park, but also deter the activities of the entire park management towards ecotourism development. Lack of portable water within the enclave communities has influenced the proliferation of certain water-borne diseases in the area. This situation does not only affect the local residents, but also tourists and park rangers. Result also shows that enclave communities have only one primary and one secondary school with poor facilities and unqualified teachers at Okwanwo, which is very far from Okwa and other surrounding communities. Because of the distance, majority of the children are discouraged from going to school, but resort to hunting and collection of non-timber forest products and agricultural practices that are not sustainable, thus corroborating the result of Eja et.al (2013) that ecotourism benefits in Okwango zone have not been achieved because government have failed to provide infrastructural development in the area of electricity, communication network, portable water, health facilities, good schools and good road network thus; hindering the mobilization of resources that would have influenced the growth of ecotourism to bring the much needed socio-economic benefits in the area. The population of communities living inside the park has increased with a corresponding high rate of livelihood needs compared to available resources that are accessible to them. This has greatly affected their local economy as they no longer have access to exploit the forest resources that give them money. Formal employment within the support zone communities is very low, thus encouraging high level of poverty particularly among residents of the enclave communities. This situation often provoked their actions towards exploiting the park resources for their survival despite their knowledge of the park laws, thus affecting the goals of resource conservation for ecotourism development. This findings tallies with that of Anselem and Nzanosim (2016) that rural duelers of Okwangwo Division feel cheated and have continued to trespass into the park area in search of traditional forest sources for survival, despite the legislation in place. Host communities, especially the enclave communities have mixed feelings towards the ecotourism project in the area. This is attributed to the ban by park authorities on construction of vehicular access road into their communities and the failure of the government to relocate them out of the park.

It is realized from the findings that the challenges facing ecotourism development within the support zone communities of Okwangwo Division are diverse. In spite of the fact that the major actors (Government and NGOs) claim to have put in their best towards achieving their target, they are blamed for the poor infrastructural supply and development within the park. As pointed out by Ebin (2003), government has failed to provide amenities and adequate incentives and alternative means of livelihood by way of relocation (enclave communities) and creation of opportunities for socio-economic benefits which has led to unfriendly attitudes of host communities towards the park.

Result revealed possibility of conflict between park authority (government) and host communities due to government negligence of the area. Local residents believe that the government is depriving them of their God given forest without providing a corresponding alternative source of survival. This supports the result of (Ebin 2003) that revealed the unfriendly relationship between park authorities and host communities culminating in confrontation and constant depletion of ecotourism resources and attack of park staff. The government have not reconciled its conservation initiative with alternative sources of livelihood and provision of social amenities as promised from the onset of the programme. Thus, since indigenous people depend largely on the natural forest for survival, any slightest provocation results in conflict.

\section{Conclusion and Recommendations}

This study has succeeded in identifying a range of issues hindering the development of ecotourism in Okwangwo Division of Cross River National Park. Despite ample potentials for tourism activities in the Division, host communities and developers alike are yet to reap the benefits of ecotourism in the area. inadequate infrastructure and amenities, role conflict and increase population of park communities has been identified as the major challenges of tourism development in the area. Ecotourism has been promoted for its ability to enhance local economic growth and environmental conservation. However, where ecotourism project is predicated on poor funding and mixed feelings about the success of the programme, its objectives as a prerequisite to sustainable tourism development cannot be realized. Therefore, for ecotourism to be successful and beneficial to both developers and local communities in Okwangwo Division, concerted efforts should be geared by government towards the provision of infrastructure and amenities, effective ways of channeling information, and control of park population to avoid pressure on the resources. Since poor funding has been identified as the bane of ecotourism failure in Okwangwo, government should contract the ecotourism component of the park to competent 
private organization that is willing and ready to operate in accordance with best practices.

\section{References}

Abdul Malek Hazbar, H. A. and Anand, D. (2009). Economic and Environmental Impact of Tourism on Socotra Island. Southern Economist. 15(3): 21-33.

Agbor, E. E. (2014). An Assessment of Local Community Involvement in Community-Based Ecotourism Planning and Development: The Case of Takamanda National Park, South-West Region, Cameroon. North Cyprus: Gazimagusa

Allock, A., Jones, B., Lane, S. and Grat, J. (1994). National Ecotourism Strategy. Cnberra, Australia: Australian Government Publishing Service.

Anselem, P. E. and Nzanosim, M. Nzanosim (2016). Host Communities Contribution to Ecotourism and Conservation: A Case Study of Mbe Mountain. Unpublished Seminar Paper, Cross River University of Technology, Calabar.

Augustine Ugar Ogogo, Sijah Agbor Asuk and Rebecca Victor Ikpeme (2014). Evaluation of the Anti-Poaching Programme of the Cross River National Park Okwango Division, Nigeria 2002 to 2013. Open Journal of Forestry. 4: 507-511. http://www.scirp.org/journal/ojf. Accessed 3/2/2020.

Ayele A. M. (2011). Ecotourism as a sustainable development option: case study from Bale Mountans National Park. Unpublished Master Thesis, Addis Ababa University, Addis Ababa, Ethiopia. Pp. 1-124.

Aynalem S. (2016). Key stakeholders roles in tourism development in Bale Zone, Ethiopia. World Academic Journal of Business Management and Administration, 1: 1-4.

Bale Mountains National Park (2014). Annual Magazines. Bale: Mnp.

Bates, B. (1991). Ecotourism: A Case Study of the Lodges in Papau New Guinea. Paper presented at the PATA $40^{\text {th }}$ Annual Conference, April $10^{\text {th }}-13^{\text {th }}$, Nusa Indah conversion centre, Bali, Indonesia.

Buckley, R. (2004). Partnerships in Ecotourism: Australian Political Frameworks. International Journal of Tourism Researc. 6(2): 75-83.

Carter, E. (2006). Ecotourism as a Western Construct. Journal of Ecotourism. 5(1\&2). 23-39.

Ceballos-Lascurain H. (2006). "Arg. Hector Ceballos-Lascurain: The Architect of Ecotourism". ECOCLUB: International Ecotourism Monthly, 85: 2-4.

Ceballos-Lascurain, H. (2002). Preface In: Global Ecotourism Policies and Case Studies: Perspectives and Constraints. Current Issues in Tourism. 5(3 and 4): 20-36

Chambers, R. (1995). Participatory Rural Appraisal: Challenges, Potentials and Paradigm. World Development. 22(10): 176-179.

Ebin, C. O. (2003). Assessment of Host Communities Attitude towards Okwangwo Division of Cross River National Park, Nigeria. Unpublished PhD Thesis, University of Ibadan: Oyo State.

Eja Eja, Out, Judith E., Agbor, Emmanuel A. and Emri, Samuel I. (2013). Community Leadership and Attitude to Impact of Ecotourism Development in Cross River State. Journal of Studies in Social Science. 3(2): 151-163

Eneji, Chris-Valentine O. (2015). Assessment of Gender Participation in the Exploitation of Forest Resources for Rural Development of the Enclave Communities of Cross River National Park, Nigeria. Unpublished PhD Thesis, Frderal University Yola: Adamawa State.

Ewah, J. O. (2013). Survival Strategies of Support Zone Communities in Cross River National Park, Okwangwo Division 1990 to 2010. International Journal of Humanities and Social Science. 3(1): 238 -245.

Isreal P. Membere and Timer P. Membere (2017). Opportunities and Challenges for Community-Based Ecotourism Development: A Case Study in Dinsho and Goba Woredas, South-East Ethiopia. International Journal of Ecology and Ecosolution. 4(1): 5-16. http://www.netjournals.org/pdf/IJEE/2017/1/16-024.pdf. Accessed 18/2/2020.

Johnston, A. (2000). Indigenous Peoples and Ecotourism. Tourism Recreatio Research. 25(2): 89-96.

Ketema D. T. (2015b). inside the commons of ecotourism development in Ethiopia: Strategic communal empowerment or marginalization? Evidence from Wenchi community based ecotourism. International Journal of Biodiversity and Conservation. 7: 429-437.

Kothari, A. N., Singh and Suri, S. (1996). People and Protected Areas: Towards Participatory Coservation in India. New Delhi: Sage Publications.

Liu, Z. H. (2003). Sustainable Tourism Development. A critique Journal of Sustainable Tourism. 11(6): $315-332$

Mequanint F. \& Gebremedhin S. (2015). Contribution of local community for Ecotourism Development in and around Abijata-Shalla Lakes National Park with Emphasis to Women's Role, Ethiopia. Australian Journal of Social Science. 1: 1-19.

Nwahia, O. C., Omonona, B. T., Onyeabor, E. N. and Balogun, O. S. (2012). An Analysis of the Effect of Obudu Community Participation in Ecotourism on Poverty. Journal of Economics and Sustainable Development. 3(8): 29-40

Okpoko, P.U., Emeka, E.E., and Diminyi, C.A. (2011). Understanding Tourism. Onitsha: EFS Allied Publishers 
Ltd.

Osunsina, I. O. O., Ogunjinmi, A. A., Meduna, A. J. and Oyeleke, O. O. (2008). Ecotourism Potentials of Kamuku National Park, Birnin Gwari, Kaduna State. ASSET Series A. 8(2): 214-224.

Pookhao N. (2014). Community-based ecotourism: The transformation of local community. SHS Web of Conferences. 12: 1-8.

Scheyvens, R. (1999). Ecotourism and the Empowerment of Local Communities. Tourism Management. 20: 245249.

Sebele, L. S. (2010). Community-Based Tourism Ventures, Benefits and Challenges: Khama Rhio Sanctuary Trust, Central District, Botswanna. Tourism Management, 31(1): 136-146.

Tobias Ramser (2007). Evaluating Ecotourism in Laikipia, Kenya. Berne: Center for Development and Environment.

UNWTO (2012). World Tourism Barometer. Vol. 10, United Nations, United Nations World Tourism Organization. Madrid, Spain.

World Bank (2013). Regional Study on Community-Based Tourism in the Caucasus.

WTTC (2019). Global Tourism Statistics. https:/www.wttc.org/.../travel-tourism-continues-strong-growth-aboveglobal-gdp. Accessed 20/12/2019

WTTC (2014). Travel and Tourism Economic Impact, 2014 Nigeria. London: WTTC. 